\title{
Pelaksanaan Abdimas Pembekalan Digital Marketing Bagi Jemaat GKI
}

\author{
Melitina Tecoalu ${ }^{1}$, Hery Winoto $\mathrm{Tj}^{2}$, Soegeng Wahyoedi ${ }^{3}$, Saparso ${ }^{4}$, Oktavia $^{5}$, Subagyo ${ }^{6}$, Daniel Widjaja ${ }^{7}$, Gatot \\ Gunarso $^{8}$, Fredella Colline ${ }^{9}$, Dwi Aprillita ${ }^{10}$, Oki Sunardi ${ }^{11}$ \\ ${ }^{1,2,3,4}$ Program Studi Magister Manajemen,Universitas Kristen Krida Wacana \\ Jl. Tanjung Duren Raya No. 4 Jakarta Barat 11470 \\ ${ }^{1}$ melitina@ukrida.ac.id \\ ${ }^{2}$ hery.winoto@ukrida.ac.id \\ ${ }^{3}$ swahyoedi@ukrida.ac.id \\ ${ }^{1}$ saparso@ukrida.ac.id \\ ${ }^{5,6}$ Program Studi Akuntansi,Universitas Kristen Krida Wacana \\ Jl. Tanjung Duren Raya No. 4 Jakarta Barat 11470 \\ 5oktavia@ukrida.ac.id \\ 6subagyo@ukrida.ac.id \\ 7,8,9,10 Program Studi Manajemen,Universitas Kristen Krida Wacana \\ Jl. Tanjung Duren Raya No. 4 Jakarta Barat 11470 \\ 7daniel.widjaja@ukrida.ac.id \\ 8gatot.gunarso@ukrida.ac.id \\ ${ }^{9}$ fredella.colline@ukrida.ac.id \\ ${ }^{10}$ lita@ukrida.ac.id \\ ${ }^{11}$ Program Studi Teknik Industri, Universitas Kristen Krida Wacana \\ Jl. Tanjung Duren Raya No. 4 Jakarta Barat 11470 \\ ${ }^{11}$ oki.sunardi@ukrida.ac.id
}

\begin{abstract}
Abstrak-Jemaat Gereja Kristen Indonesia (GKI) adalah bagian dari komunitas masyarakat, dimana di dalamnya merupakan anggota jemaat yang terdiri dari berbagai macam profesi, dimana salah satunya adalah berprofesi sebagai wirausaha. Adapun wirausaha yang digeluti oleh beberapa anggota jemaat adalah termasuk dalam kategori Usaha Mikro Kecil Menengah (UMKM). Anggota Jemaat yang memiliki Usaha Mikro Kecil Menengah tersebut belum sepenuhnya mengetahui dan memahami bagaimana mereka dapat berupaya untuk meningkatkan hasil produknya dapat dijual ke masyarakat luas sampai pelosok luar Jakarta. Oleh karena hal tersebut Fakultas Ekonomi dan Bisnis (FEB) bersama Fakultas Teknik dan Ilmu Komputer (FTIK) siap berkontribusi melakukan kegiatan pengabdian kepada masyarakat di lingkungan Jemaat Gereja Kristen Indonesia (GKI) tersebut. Implementasi pelayanan dalam bidang pengabdian kepada masyarakat merupakan salah satu kewajiban yang harus dipenuhi Perguruan Tinggi yang berkecimpung dalam dunia pendidikan yakni Trdharma
\end{abstract}

Perguruan Tinggi. Adapun kegiatan pengabdian kepada masyarakat ini dilaksanakan dengan kolaborasi 2 (dua) Fakultas yang ada di UKRIDA yaitu berupa penyelenggaraan kegiatan Seminar dan Pelatihan mengenai Digital Marketing yang diberikan oleh beberapa Dosen FEB dan FTIK sebagai Narasumber sesuai kompentensinya. Diharapkan setelah selesai kegiatan tersebut, ada perubahan yang dicapai oleh Jemaat GKI yang telah mengikuti Seminar tersebut, sehingga terlihat manfaatnya.

Kata kunci-Jemaat GKI, UMKM, pemasaran digital, Perguruan Tinggi.

Abstract-The Indonesian Christian Church (GKI) Congregation is part of the community, which includes members of the congregation consisting of various professions, one of which is an entrepreneur. The entrepreneurship that some members of the congregation engage in is included in the 
category of Micro, Small and Medium Enterprises (MSMEs). The members of the GKI who have Micro, Small and Medium Enterprises do not fully know and understand how they can try to increase their product yields so that they can be sold to the wider community to remote areas outside Jakarta. Because of this, the Faculty of Economics and Business (FEB) together with the Faculty of Engineering and Computer Science (FTIK) are ready to contribute to community service activities within the Indonesian Christian Church (GKI) Congregation. The implementation of services in the field of community service is one of the obligations that must be fulfilled by universities that are involved in the world of education, namely the Tdharma of Higher Education. This community service activity is carried out in collaboration with 2 (two) Faculties at UKRIDA, namely in the form of organizing Seminars and Training activities on Digital Marketing given by several lectures of FEB and FTIK according to their competencies. It is hoped that after the activity, there will be changes achieved by the GKI Congregation who have attended the seminar, so that the benefits can be seen.

Keywords-The Indonesian Christian Church (GKI) Congregation, SMEs, digital marketing, Higher Education.

\section{PEndahuluan}

Peran wirasusaha sangat dibutuhkan sebagai pendorong perubahan kemajuan perekonomian suatu negara sebagai salah satu inovasi.[1] Dibutuhkan orang-orang yang memiliki kemampuan dalam mengambil resiko untuk mempercepat pertumbuhan ekonomi. [2] Hal ini sesuai dengan instruksi Presiden RI No 4 Tahun 1995 yang berbunyi : "kewirausahaan adalah semangat, sikap, perilaku, dan kemampuan seseorang dalam menangani usaha atau kegiatan yang mengarah pada pencarian, menciptakan, menerapkan cara kerja, teknologi dan produk baru dengan meningkatkan efisiensi dalam rangka memberikan pelayanan yang lebih besar. [2]

Para ahli perpendapat, kewirausahaan merupakan suatu proses dinamis untuk menciptakan penambahan kekayaan bagi seseorang atau individu yang berani mengambil resiko utama dengan syarat kewajaran, waktu dan komitmen yang berkaitan dengan penciptaaan kegiatan atau usaha atau aktivitas bisnis berdasarkan kemauannya sendiri sesuai kemampuannya.[2][3]

Tahun 2020, tepatnya pada bulan Maret, sejak dinyatakannya adanya wabah Virus Covid-19, aktivitas bisnis secara otomatis terkena dampak menurunnya roda perekonomian suatu negara. [4] Bisnis yang dijalani mulai tersendat karena adanya pembatasan keleluasaan pergerakan, terlebih adanya pemberlakuan Pembatasan Sosial Berskala Besar (PSBB) yang dicanangkan oleh Pemerintah RI.[2] Usaha Mikro Kecil Menengah (UMKM) adalah bagian yang sangat merasakan dampak akibat wabah Virus Covid-19 ini, padahal sektor UMKM ini adalah merupakan sektor penyumbang terbesar perekonomian dalam membantu perkembangan pembangunan ekonomi suatu negara.[1] Keadaan seperti ini menimbulkan pemikiran bagi suatu Perguruan Tinggi untuk membantu memberikan solusi agar aktivitas bisnis tetap berjalan walaupun keadaan negara masih belum pulih dari virus Covid-19. Salah satu strategi yang ditawarkan adalah memberikan pencerahan mengenai "Digital Marketing" untuk menjawab kesulitan agar usaha bisnis tetap berjalan dengan baik di masa sulit Pandemi Covid-19.

Bukan hal yang tidak mungkin digital marketing dijadikan sebagai salah satu andalan bagi para pelaku bisnis UMKM. [5] [6]Selain sebagai salah satu kebutuhan yang penting, digital marketing ini pun dapat menunjang keefisiensian dalam menjalankan usaha bisnis tersebut, dan bahkan dapat meningkatkan penjualan dalam bisnis kita, karena menjangkau kalangan luas, tersebar dengan cepat, dan bahkan memudahkan serta dapat lebih dekat dengan konsumen namun tetap mematuhi kebijakan program PSBB Pemerintah. Konsep dan penerapan digital marketing adalah hal yang dilakukan untuk mendongkrak penjualan produk yang ditawarkan UMKM.[7]

Sektor bidang UMKM inipun banyak dimiliki oleh Jemaat Gereja Kristen Indonesia (GKI) yang merupakan bagian dari komunitas masyarakat. Sejak adanya Pandemi Covid-19 banyak anggota Jemaat GKI yang memiliki usaha bisnis tersendat aktivitasnya, padahal mereka harus survive demi memenuhi kebutuhan keluarganya.[5] Sebagai salah satu bagian dari GKI yang bernaung dalam Sinode GKI, UKRIDA prihatin atas masalah yang dihadapi sebagian warga Jemaat GKI. Oleh karena itu, sebagai salah satu kewajiban tugas Perguruan Tinggi dalam mengimplementasikan tridharma Perguruan Tinggi adalah pengabdian kepada masyarakat. Implementasi pelayanan dalam bidang pengabdian kepada masyarakat ini harus dipenuhi oleh Perguruan Tinggi, dan dilakukan oleh kolaborasi 2 (dua) Fakultas yang ada di UKRIDA yakni Fakultas Ekonomi dan Bisnis (FEB) dan Fakultas Teknik dan Ilmu Komputer (FTIK) UKRIDA. Beberapa Dosen FEB dan FTIK sesuai kompetensinya menjadi Narasumber dalam penyelenggaraan Seminar pembekalan Digital Marketing bagi Jemaat GKI yang masih minim keahlian dan pengetahuannya terkait digital marketing.[8][9]

Diharapkan rencana pencapaian adanya perubahan akan dirasakan Jemaat GKI yang telah mengikuti kegiatan Seminar yang diselenggarakan oleh kedua Fakultas UKRIDA, sehingga terlihat manfaatnya.

Rencana kedepannya, Fakultas Ekonomi dan Bisnis Universitas Kristen Krida Wacana dapat melakukan kegiatan Workshop sebagai keberlanjutan kegiatan pembekalan ini sebagai wujud implementasinya. 


\section{METODE PELAKSANAAN}

Proses pelaksanaan implementasi kegiatan pengabdian kepada masyarakat mengenai pembekalan Digital Marketing bagi warga GKI adalah sebagai berikut :

\section{G. Persiapan intern}

Fakultas Ekonomi dan Bisnis (FEB) dan Fakultas Teknik dan Ilmu Komputer (FTIK) UKRIDA melakukan pertemuan-pertemuan melalui rapat intern guna membahas topik-topik yang cocok dengan yang dibutuhkan oleh warga Jemaat GKI, dimana sebelumnya telah ada pertemuan evaluasi pembahasan dengan beberapa perwakilan warga Jemaat GKI.

\section{H. Pelaksanaan teknis}

- Penunjukkan Panitia Pelaksana Penyelenggara Kegiatan Seminar yang terdiri dari Dosen dan Tenaga Pendidik (Tendik), untuk mempersiapkan surat-surat pemberitahuan ke warga GKI, pembuatan poster atau flyer sebagai media informasi, penyiapan link zoom Seminar, penyiapan desain e-sertifikat bagi peserta, dan sebagainya.

- Melakukan pembagian tugas materi yang akan disampaikan oleh Narasumber sesuai kompetensi keilmuannya sebagai Dosen FEB dan FTIK.

- Menentukan bentuk pelaksanaan kegiatan Seminar dengan cara Seminar online, untuk turut mendukung kebijakan program Pemerintah mengurangi penyebaran virus Covid-19.

\section{Pelaksanaan hari $H$}

Peserta yang telah mendaftarkan diri melalui https://cutt.ly/pelatihan_kwu, mendapat balasan dari Panitia Penyelenggara melalui email kepada peserta untuk mendapat $I D$ dan Password, agar peserta pendafttar dapat bergabung secara online. Peserta adalah warga Jemaat GKI yang bernaung di bawah Sinode Wilayah Jawa Barat. Jumlah peserta dibatasi sampai batas 50 orang, agar pertemuan lebih efektif.

Adapun agenda acara kegiatan sebagai berikut :

TABEL I

RANGKAIAN SUSUNAN ACARA KEGIATAN

\begin{tabular}{|c|l|l|}
\hline Waktu & Keterangan Kegiatan & \multicolumn{1}{|c|}{ Pelaksana } \\
\hline $08.00-08.30$ & Briefing Panitia & UKRIDA, GKI \\
\hline $08.30-09.00$ & $\begin{array}{l}\text { Persiapan Acara + Lagu- } \\
\text { lagu }\end{array}$ & Ukrida \\
\hline
\end{tabular}

\begin{tabular}{|c|c|c|}
\hline $09.00-09.05$ & Pembukaan oleh MC & Ukrida \\
\hline $09.05-09.10$ & $\begin{array}{l}\text { Doa Pembukaan - (Pdt. } \\
\text { Alexander Urbinas) }\end{array}$ & GKI \\
\hline $09.10-09.15$ & $\begin{array}{l}\text { Sambutan dari UKRIDA - } \\
\text { (Dr. Oktavia selaku Wakil } \\
\text { Rektor II Universitas } \\
\text { Kristen Krida Wacana) }\end{array}$ & UKRIDA \\
\hline $09.15-09.20$ & $\begin{array}{l}\text { Sambutan dari GKI SW } \\
\text { JABAR - (Pdt. Cordelia } \\
\text { Gunawan - Sekretaris } \\
\text { Umum BPMSW GKI SW } \\
\text { JAWA BARAT) }\end{array}$ & GKI \\
\hline $09.20-09.25$ & Sesi Foto Bersama & UKRIDA, GKI \\
\hline $09.25-10.25$ & $\begin{array}{l}\text { Serba-serbi menjadi } \\
\text { Entrepreneur Oleh DR } \\
\text { Melitina Tecoalu, DR Oki } \\
\text { Sunardi (Dipandu oleh } \\
\text { Subagyo) }\end{array}$ & UKRIDA \\
\hline $10.25-12.00$ & $\begin{array}{l}\text { Digital Marketing dan } \\
\text { Trend Konsumen } 2021 \\
\text { (Oleh Bapak Gatot } \\
\text { Gunarso) }\end{array}$ & UKRIDA \\
\hline $12.00-13.00$ & Istirahat & UKRIDA, GKI \\
\hline $13.00-15.00$ & $\begin{array}{l}\text { Workshop Digital } \\
\text { Marketing (Dipandu oleh } \\
\text { Bapak Gatot Gunarso \& } \\
\text { Daniel Widjaja) } \\
\end{array}$ & UKRIDA \\
\hline $15.00-$ & Penutup & UKRIDA \\
\hline
\end{tabular}

\section{HASIL PEMBAHASAN}

Keberlangsungan penyelenggaraan kegiatan :

D. Materi yang disampaikan Narasumber 


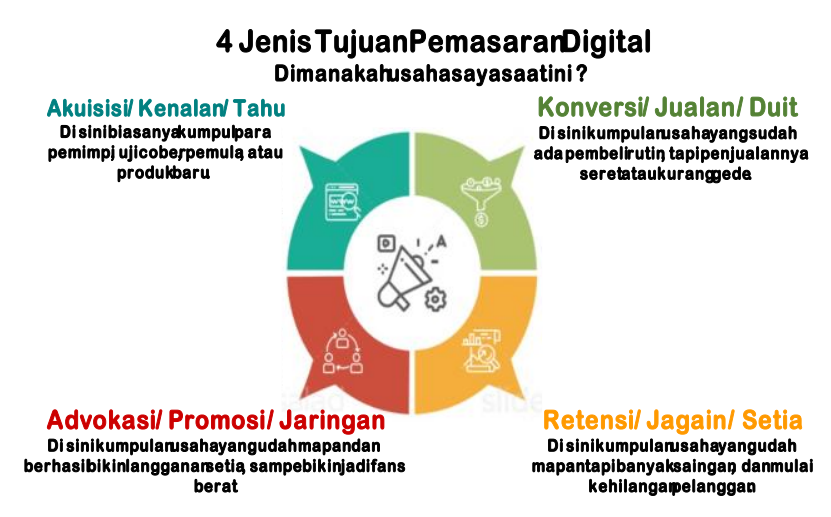

\section{PerjalananSang Pembeli (dalampikirannyä)}

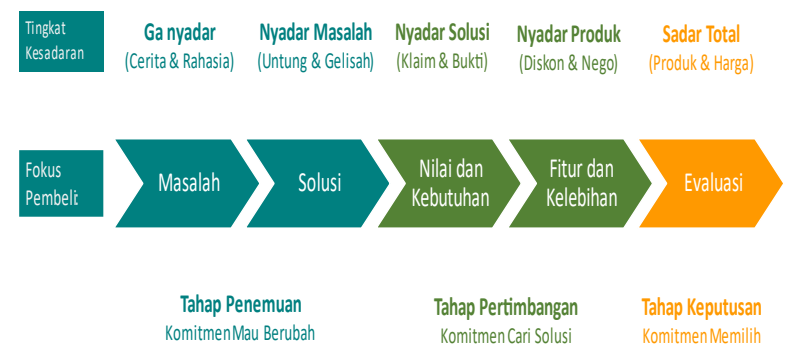

\section{CaraBikin PembeliJadiSETIA}

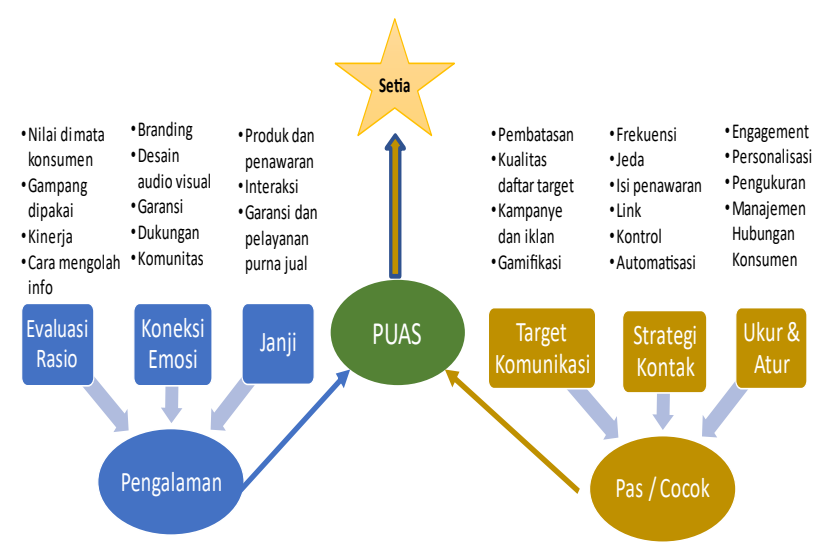

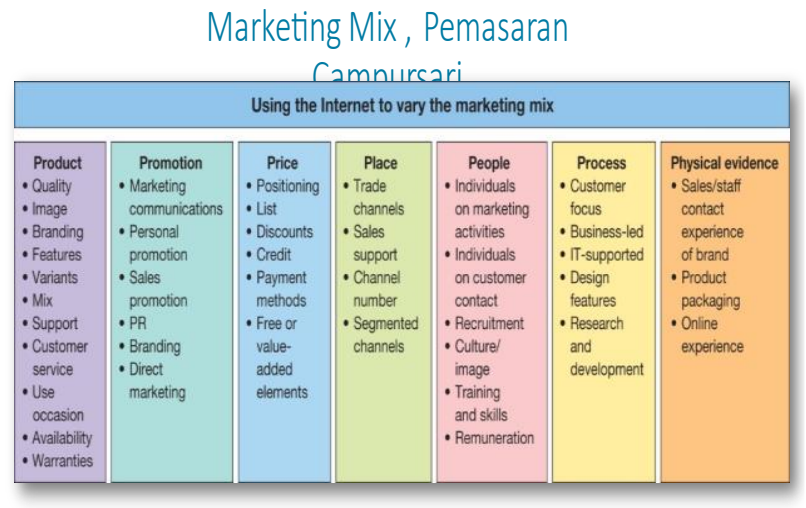

* $8^{\text {th }}$ P: Partnership, Comarketing

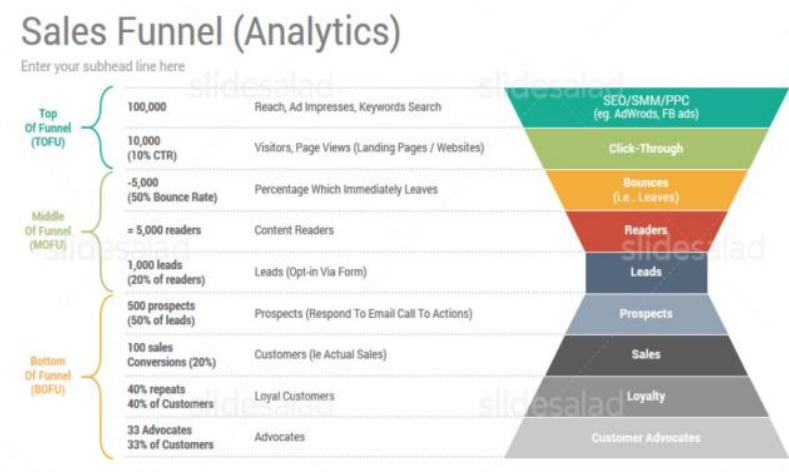

Gambar 1. Materi [10]

E. Tahapan Pelaksanaan Kegiatan :

1. Panitia Penyelenggara meminta alamat-alamat email GKI yang termasuk dalam lingkungan GKI Wilayah Jawa Barat kepada Sinode GKI.

2. Penyebaran poster dan flyer melalui alamat e-mail GKI Wilayah Jawa Barat. 


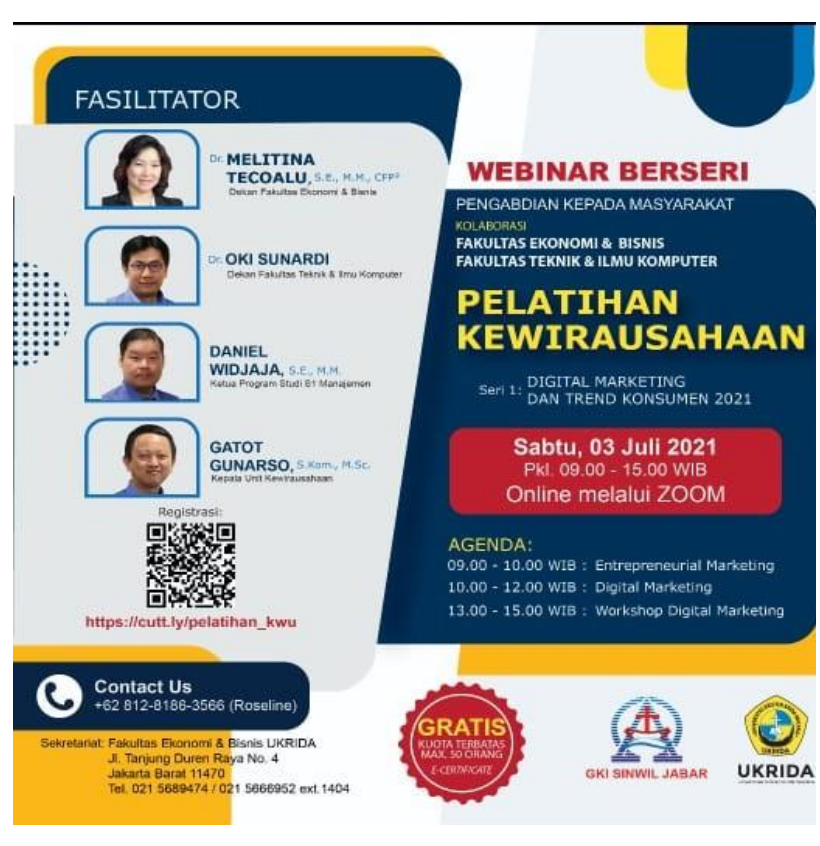

Gambar 2. Penyebaran poster/flyer

3. Pendaftaran peserta melalui link yang dicantumkan dalam flyer digital dengan alamat

https://cutt.ly/pelatihan_kwu.

4. Panitia Penyelenggara memberikan link zoom berupa ID dan Password untuk Seminar online yang terdaftar dalam sheet google form melalui e-mail masing-masing peserta sesuai yang dicantumkan oleh peserta.

5. Panitia Penyelenggara menyediakan google form evaluasi yang diisi oleh para peserta yang harus diisi pada akhir acara.

6. Panitia menyediakan e-sertifikat bagi peserta, dengan desain sebagai berikut :

7.

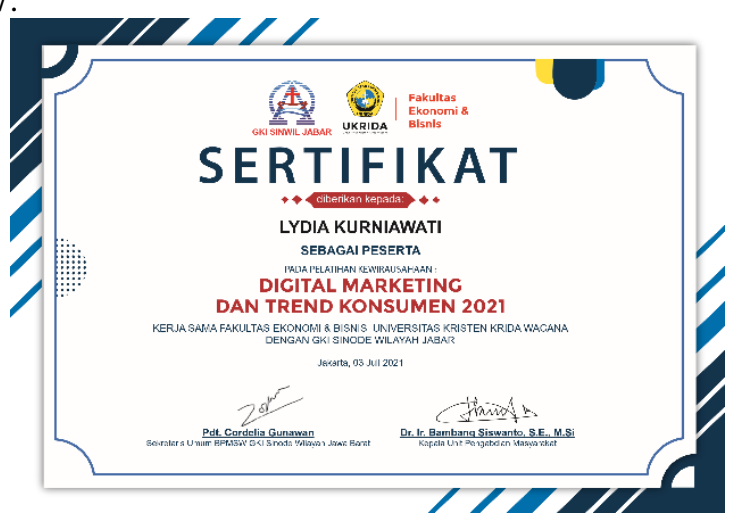

Gambar 3. Contoh e-sertifikat untuk peserta

8. Pelaksanaan kegiatan terselenggara pada hari Sabtu tgl 03 Juli 2021, pukul 09.00-15.00 secara online melalui zoom.

\section{F. Hasil Evaluasi Peserta}

Tidak semua peserta mengirimkan lembar evaluasi dari kegiatan yang dilaksanakan pada hari itu, namun dari peserta yang mengirimkan hasil evaluasi kegiatan seminar pembekalan Digital Marketing, memberikan penilaian baik dan sangat baik untuk penguasaan materi yang dibawakan oleh pembicara rata-rata nilai 4-5, penyampaian materi yang dibawakan oleh pembicara rata-rata memberikan penilaian 4-5, untuk topik yang dibawakan dalam pelatihan semua memberikan nilai 5, dan materi yang dibawakan sesuai dengan harapan dan kebutuhan mendapatkan penilaian 4-5. Adanya beberapa saran tema yang disampaikan oleh peserta yakni, mengenai kepuasan pelanggan dan kesetiaan pelanggan, kampanye digital, dan pendampingan dan pengarahan memulai/melanjutkan bisnis.

\section{G. Dokumentasi Rangkaian Kegiatan}

Kegiatan Seminar online ini dimulai tepat pada pukul 09.00 sesuai susunan acara. Dalam sambutan kata pengantar oleh Wakil Rektor II UKRIDA (ibu Dr. Oktavia, S,E, M.Ak), menyatakan apresiasi atas kehadiran peserta yang hadir tepat waktu, dan mengharapkan materi yang disampaikan oleh Narasumber akan sesuai kebutuhan warga Jemaat GKI saat ini.

Narasumber sesuai masing-masing kepakarannya memberikan materi sesuai topik dalam susunan acara dengan waktu yang ditetapkan Panitia dipandu oleh seorang Moderator. Diakhiri dengan workshop dengan memberikan contoh bagaimana tahapan-tahapan menjalankan digital marketing, dimana peserta boleh langsung bertanya dan narasumber memberikan respon solusi bagi penanya, sehingga peserta dapat mempraktekannya langsung setelah selesai kegiatan Seminar.

Dokumentasi berlangsungnya kegiatan adalah sebagai berikut :

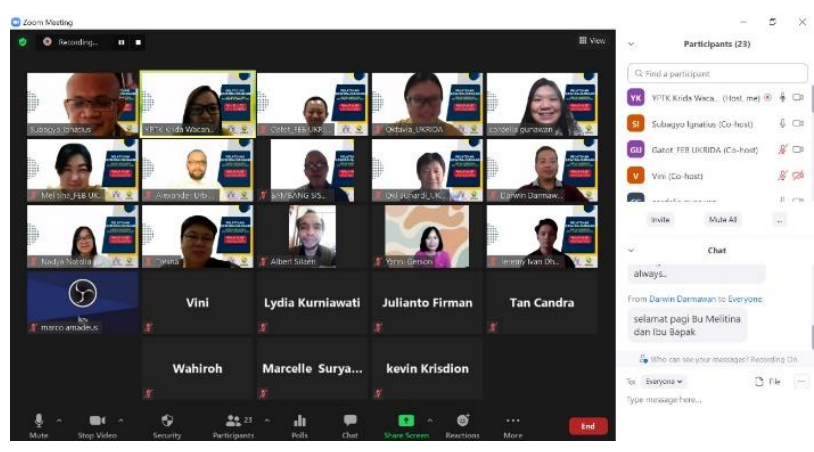




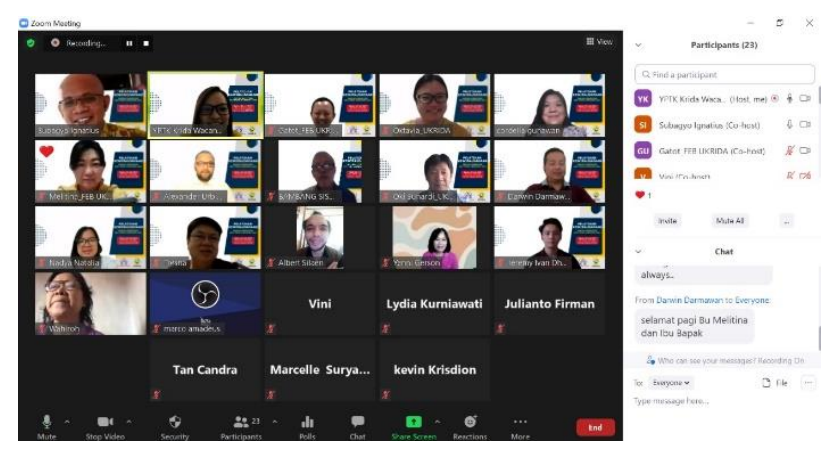

Gambar 4. Peserta warga Jemaat GKI

Panitia Penyelenggara berharap agar materi yang telah disajikan para Narasumber dapat bermanfaat dan dapat digunakan secara langsung oleh peserta untuk kedepannya. Di akhir acara sebelum Panitia Penyelenggara memberikan e-sertifikat bagi para peserta, diminta kesediaan para peserta untuk mengisi lembar evaluasi yang diberikan Panitia melalui link google form.

\section{KESIMPULAN}

Penyelenggaraan kegiatan ini berjalan dengan baik dan lancar. Hasil evaluasi yang direkap oleh Panitia bahwa peserta puas dengan materi yang disampaikan para Narasumber. Selain daripada itu peserta berharap adanya kegiatan Seminar yang sama seperti yang terselenggara ini dengan topik yang berbeda seperti kampanye digital atau tentang kepuasan pelanggan dan kesetiaan pelanggan dengan melihat hasil dari evaluasi peserta yang mengisi kuesioner di akhir acara. Peserta merasakan manfaatnya sebagai antisipasi menghadapi masa Pandemi Covid-19 yang masih belum diketahui kapan berakhirnya.

Panitia Penyelenggara memberikan apresiasi tinggi kepada pseerta yang telah mengikuti kegiatan Seminar online ini dari awal hingga berakhirnya acara. Di akhir acara Panitia Penyelenggara memberikan secara simbolis esertifikat kepada salah satu peserta yang mendaftar paling awal.

\section{UCAPAN TERIMA KASIH}

Ucapan terima kasih kepada bapak/ibu peserta Seminar online yang begitu antusias mengikuti kegiatan dari awal sampai berakhirnya kegiatan.

Ucapan terima kasih kepada Panitia Penyelenggara yang telah ambil bagian mempersiapkan segala sesuatunya sehingga kegiatan Seminar online ini berjalan dengan baik dan lancar.
Ucapan terima kasih kepada Rektor Ibu Rektor UKRIDA (Dr. dr. Wani Devita Gunardi, Sp.MK (K)) atas dukungannya sehingga kegiatan pengabdian kepada masyarakat ini dapat terselenggara.

Ucapan terima kasih kepada Dekan FEB (Ibu Dr. Melitina Tecoalu, S.E., M.M., CFP®, CHCP-A) dan Dekan FTIK (Bapak Dr. Oki Sunardi) UKRIDA yang telah mendukung sehingga kegiatan Seminar online dapat terselenggara sebagai wujud implementasi salah satu bentuk pengabdian kepada masyarakat.

\section{DAFTAR PUSTAKA}

[1] Istiatin, "Sosialisasi Berbagai Peluang Usaha UMKM dan Ekonomi Kreatif di Era New Normal di Dusun Pinggir Desa Telukan Sukoharjo," Budimas, vol. 03, no. 01, p. 6, 2021.

[2] "Kewirausahaan itu apa sih ? Intip Yuk," [Online]. Available: https://www.kompasiana.com/khoiroh/591ac06a4ff9fd9033c49 e23/kewirausahaan-itu-apa-sih-intip-yuk.

[3] R. J. NAIMAH, M. W. WARDHANA, R. HARYANTO, and A. PEBRIANTO, "Penerapan Digital marketing Sebagai Strategi Pemasaran UMKM,” J. IMPACT Implement. Action, vol. 2, no. 2, p. 39, 2020, doi: 10.31961/impact.v2i2.844.

[4] "6 Manfaat Digital Marketing untuk Pengembangan Bisnis yang Lebih Potensial," [Online]. Available: https://www.tamasia.co.id/manfaat-digital-marketing/.

[5] B. B. Hapsoro, Palupiningdyah, and A. Slamet, "Peran Digital Marketing sebagai Upaya Peningkatan Omset," J. Pengabdi. Masy., vol. 23, no. 2, pp. 117-120, 2019.

[6] E. Mlinjo et al., "Peran Digital Marketing dalam Mendongkrak Omset bagi UMKM," 1 5 J. SEMAR, vol. x, No.x, no. 2, pp. 2745-4223, 2020, [Online]. Available: https://jurnal.uns.ac.id/jurnal-semar.

V. N. Tahun, "Jurnal Berdaya Mandiri Jajanan Tradisional Go Online : Sosialisasi Market ( Traditional Snacks Go Online : Market Place Socialization for Snacks Traditional SMEs," vol. 3, no. 1, pp. 529-537, 2021.

“Digital Marketing-Penabur1." .

[9] "Digital Marketing_template_SENDIMAS-2020-1rev." .

[10] "Digital Marketing-GKI-1." . 